\title{
EL PENSAMIENTO SOCIALISTA EN EL EXILIO (1939-1976). UN ANÁLISIS DE LA PRODUCCIÓN INTELECTUAL EN EL PSOE A LA LUZ DE LOS CONFLICTOS POLÍTICOS Y CULTURALES DEL LARGO CICLO DE POSTGUERRA ${ }^{1}$
}

\author{
Socialist thought in exile (1939-1976). \\ An analysis of intellectual production \\ in the PSOE in light of the political \\ and cultural conflicts of the long post-war era
}

\author{
JUAN ANDRADE \\ Universidad de Extremadura \\ jandradeb@unex.es
}

Cómo citar/Citation

Andrade, J. (2019).

El pensamiento socialista en el exilio (1939-1976). Un análisis de la producción intelectual en el PSOE a la luz de los conflictos políticos y culturales del largo ciclo de postguerra.

Revista de Estudios Políticos, 185, 105-137.

doi: https://doi.org/10.18042/cepc/rep.185.04

\section{Resumen}

El exilio entrañó una profunda reconfiguración de las bases intelectuales del PSOE. A ello contribuyeron la lectura de la intensa experiencia de la República y la Guerra Civil, las expectativas de poner fin a la dictadura o la lógica cultural de la Guerra Fría. También la permeabilidad a las nuevas tendencias culturales de los países de acogida o la influencia ejercida por los partidos socialdemócratas que le brindaron su apoyo. Este artículo analiza la evolución del pensamiento socialista en el exilio

\footnotetext{
Este articulo se ha elaborado a partir del trabajo realizado en dos estancias de investigación, una en el otońo del 2016 en Birkbeck College y otra en el verano y otońo de 2016 en Princeton University, esta última financiada por la Junta de Extremadura. Su elaboración final se enmarca en el proyecto financiado por la AEI/FEDER, «La historia de la literatura española y el exilio republicano de 1939» (FFI2017-84768-R),
} 
producido por sus intelectuales más relevantes y por aquellos dirigentes que albergaban veleidades intelectuales. Aborda las grandes obras teóricas, pero también los ensayos más livianos y los discursos y conferencias que, publicados en forma de folleto, circularon entre la militancia. Lo hace desde las perspectivas de la nueva historia política, para la cual las ideas políticas se van fraguando al fuego de los conflictos políticos, sociales y culturales de su tiempo y en un diálogo a veces problemático con su propia tradición. En este sentido, el artículo señala también las relaciones de cambio y continuidad del pensamiento socialista del exilio con el de la República y el de la Transición.

\title{
Palabras clave
}

Exilio español; PSOE; pensamiento; socialismo; Guerra Fría; intelectuales.

\begin{abstract}
The period of exile entailed a thorough reconfiguration of the intellectual foundations of the Spanish Socialist Workers' Party (PSOE). Factors that contributed to this include the lessons learned from the intense experience of the Republic and the Civil War, the variables expected to put an end to the dictatorship and the cultural logic of the Cold War, in addition to the new cultural trends in the receiving countries and the influence exercised by the social democratic parties that lent their support. This article analyses the evolution of socialist thought in exile, as produced by the most important intellectuals of the time and leaders that harbosed intellectual pretensions. It addresses great theoretical works as well as lighter essays, speeches and conferences that were published as leaflets and circulated among party members. It is written from the perspective of a new political history, with political ideas that have been forged from the political, social and cultural conflicts of the time and articulated through a dialogue that is occasionally problematic within its own tradition. Along these lines, the article also contrasts the relationships of change and continuity within socialist thought with those of the Republic and the Transition.
\end{abstract}

\section{Keywords}

Spanish exile; PSOE; thought; socialism; Cold War; intellectuals. 


\section{SUMARIO}

I. INTRODUCCIÓN. II. LOS PRIMEROS AÑOS. DIVISIÓN, ANTICOMUNISMO Y RECONCILIACIÓN: LOS PACTOS DE PRIETO. III. LA CONSTANCIA DEL SOCIALISMO LIBERAL: FERNANDO DE LOS RÍOS Y LUIS JIMÉNEZ DE ASÚA. IV. LUIS ARAQUISTÁIN: DEL SOCIALISMO REVOLUCIONARIO AL CRUDO POSIBILISMO. V. LEALTAD REPUBLICANA Y ALTERNATIVA A LA BIPOLARIDAD: MAX AUB. VI. EL PSOE EN FRANCIA: MODERACIÓN Y EUROPEIZACIÓN. VII. CONCLUSIONES. BibLIOGRAFía.

\section{INTRODUCCIÓN}

Tras la derrota en la Guerra Civil el PSOE partió al exilio agotado y dividido, con un acervo intelectual importante, aunque no tan prolífico como en otros países de Europa; un acervo sacudido por la intensa experiencia de la República y la contienda. El tiempo del exilio, al final calmo y prolongado, sirvió a una reconfiguración de las bases intelectuales del socialismo español, moldeadas por las transformaciones del largo ciclo de potsguerra y por su propia permeabilidad a las nuevas tendencias culturales de época. Con ello se desplegó dentro del socialismo espańol una compleja dialéctica de cambio-continuidad entre su tradición y esas bases reconfiguradas. Se publicaron nuevas obras, evolucionaron viejos autores y se multiplicaron las intervenciones públicas y en sus órganos internos para dar como resultado nuevos horizontes de pensamiento político.

Hablar de pensamiento político remite a un objeto de estudio extraordinariamente amplio y heterogéneo que resulta difícil de asir incluso si se restringe a la familia ideológica del socialismo y se acota a unas coordenadas temporales tan precisas como la del exilio español de 1939 a 1976. De esa amplitud da cuenta la polisemia del propio adjetivo político. Para acotar tan vasto campo aquí se analizan aquellas reflexiones que conscientemente tuvieron que ver con el hecho político en sentido estricto, es decir, aquellas centradas en el Estado, las formas del poder, las relaciones entre gobernantes y gobernados y las tradiciones ideológicas. También se presta atención a los análisis que el socialismo español hizo de su propia trayectoria, especialmente de la dura experiencia de la Guerra Civil. Igualmente se abordan los debates en torno a las posibilidades de trasformación social y cambio político, sobre todo los referidos a las vías para la superación del franquismo y la construcción de la democracia en España. 
La producción intelectual que aquí se analiza procede de dos tipos de autores, tan emparentados que a veces se confunden: los intelectuales que mantuvieron un fuerte compromiso orgánico con el PSOE y los dirigentes y cuadros del partido que por su formación o pretensiones escribieron textos y pronunciaron discursos más allá de la coyuntura. De este modo, se analizan grandes obras teóricas, aquellos ensayos más ligeros que Ortega llamaba la «ciencia, menos la prueba expresa» (Ortega, 1990: 60); y una serie de discursos en mítines, conferencias en ateneos e intervenciones en congresos del partido que luego fueron publicados en prensa, revistas teóricas, antologías o folletos. Estos últimos registros son de gran interés porque fueron la vía de acceso habitual a los debates por parte de unos cuadros y militantes intelectualmente activos que, lejos de consumir pasiva y acríticamente las ideas procedentes de arriba, construyeron las suyas propias; y fueron modelando aquellas con sus resistencias o impugnaciones.

El artículo incorpora perspectivas abiertas por la escuela de Cambridge (Skinner, 2002), la historia de los conceptos fundada por Reinhart Koselleck (2012), la historia de los intelectuales inspirada en Pierre Bourdieu (2012) y las ideas acerca del intelectual orgánico de Antonio Gramsci (2013). Pretende dejar atrás la vieja historia de las ideas políticas, para la cual estas ideas se elaboraban autónomamente en la cabeza lúcida de unos pocos intelectuales, si acaso condicionados por un contexto externo y lejano referido de soslayo, y para la cual la influencia de estas ideas se reducía a su materialización en concreciones más o menos fidedignas según su grado de asimilación social. Frente a ello estas nuevas perspectivas ponen el acento en cómo las ideas políticas se van fraguando al fuego de los conflictos políticos, sociales y culturales de su tiempo; en cómo el contexto no solo envuelve, sino que penetra en la producción discursiva; y en cómo esas ideas, además de orientar, legitimar o racionalizar una acción política, constituyen en sí mismas una acción política (Jaume, 2004: 118-120).

De acuerdo con estas perspectivas, el artículo trata de analizar la evolución del pensamiento político de los socialistas espańoles en el exilio al calor de una experiencia política, cultural y personal tensa y cambiante, marcada por múltiples factores: derrota en la Guerra Civil, dispersión territorial, división interna, falta de liderazgo unificado durante años, intentos contradictorios de pactos, negativa de los Aliados a intervenir contra Franco, contagio de las lógicas culturales de la Guerra Fría, contexto de crecimiento económico y desarrollo de las políticas redistributivas en el marco del gran pacto social de postguerra, declive en el interior en beneficio de comunistas y la nueva izquierda o dependencia y mimetización con los referentes socialistas de los países de acogida; a lo cual habría que sumar las diferentes trayectorias formativas, militantes y vitales de quienes escribieron en cada momento. 
La condición de exiliado - la deuda con respecto a un proyecto abortado, la desubicación territorial o el anhelo de patria- influyó en las formas de pensar del socialismo espańol. Los socialistas en el exilio pensaron constantemente sobre España y lo hicieron desde los marcos categoriales forjados con los aires de la República y el fuego de la Guerra Civil. La derrota política y el desgarro personal condujeron a la búsqueda pertinaz de sentido para las posiciones de antaño y a recurrir con frecuencia a una lectura terapéutica del pasado que ayudase a la supervivencia moral en una patria ajena. En ocasiones la dimensión práctica de los debates políticos quedó desbordada por un fuerte sentido ético e incluso dramático. Debatir, por ejemplo, acerca de la conveniencia o no de apostar por la restitución de la República como vía para el restablecimiento de la democracia en España suponía hacerlo acerca de la lealtad a un proyecto cuya defensa era la causa de su exilio y en el que habían arraigado su propia identidad una vez esta se había desarraigado territorialmente.

Sin embargo, el pensamiento socialista en el exilio no fue un pensamiento nacionalmente ensimismado ni lastrado por la nostalgia. De hecho, la condición de exliado contribuyó a internacionalizar el pensamiento socialista en al menos tres sentidos: en el de prestar atención preferente a las dinámicas internacionales, que tanto afectaban a España; en el de interesarse por las realidades de los países de acogida; y en el de verse muy influidos por la corrientes intelectuales y culturales de estos.

\section{LOS PRIMEROS AÑOS. DIVISIÓN, ANTICOMUNISMO Y RECONCILIACIÓN: LOS PACTOS DE PRIETO}

El PSOE terminó la Guerra Civil dividido y descompuesto. De todos los partidos del Frente Popular sufrió más que ninguno los conflictos que atravesaron a la República. Ello fue así porque a las tensiones procedentes de los años veinte se sumaron los enfrentamientos derivados de la posición central que el partido ocupó en aquel complejo conglomerado que fue el Frente Popular y el Gobierno de la República durante la contienda, dentro del cual desempeńó, entre otros cargos importantes, dos presidencias del Gobierno. Por el PSOE pasaron muchas de las principales decisiones sobre la orientación política del proyecto republicano, la estrategia militar y las relaciones internacionales. Las decisiones en torno cuestiones tan trascendentales fueron ahondando las fisuras abiertas desde hacía tiempo.

Si hablar del Frente Popular era un anacronismo a finales de la Guerra Civil (Martín Ramos, 1989: 8), hablar del PSOE en los primeros años del exilio era hacerlo, en realidad, de varias facciones enfrentadas, si no de varios 
partidos distintos. A la altura de 1940 podía computarse, por un lado, el PSOE de Ramón Lamoneda y Ramón González Peńa, que a duras penas soportaba a Juan Negrín como cabeza del Gobierno republicano en el exilio. En frente estaban algunas personalidades vinculadas a un besteirismo ya prácticamente extinto, sectores nucleados alrededor del liderazgo carismático de Indalecio Prieto y, sobre todo, la base militante, todavía amplia, del viejo caballerismo. En España, derrotados y perseguidos, los socialistas que no habían logrado pasar la frontera estaban más atentos a su propia supervivencia.

Durante sus primeros ańos en el exilio, el PSOE logró recomponerse orgánicamente alrededor del grupo de Toulouse encabezado por Rodolfo Llopis, principal representante de un caballerismo muy escarmentado de sus recientes veleidades revolucionarias. La preeminencia orgánica del núcleo de Toulouse se explica por el esfuerzo organizativo acometido, por la concentración de militantes socialistas en el sur de Francia y por su mayor conexión con los restos del socialismo en el interior. Pese a ello, la iniciativa política cayó en manos de Indalecio Prieto, sobre todo tras la expulsión del partido de los negristas en 1946 (Juliá, 1997: 294). La preminencia de Prieto se debió a su amplia trayectoria, a su fuerte carisma y a su revitalizada energía; pero además se vio favorecida por la desaparición de otras dos figuras que podían hacerle sombra: Besteiro murió en la cárcel de Carmona en septiembre de 1940 y Largo Caballero adoptó un perfil bajo tras el calvario que vivió durante la Segunda Guerra Mundial y hasta su muerte en 1946.

Con Prieto al frente del partido u obrando entre bastidores, el PSOE diseñó durante el primer tramo del exilio una lenta y zigzagueante trayectoria conducente al abandono de la reivindicación de la restauración de la República. La alternativa se fue definiendo sobre la marcha y consistió, finalmente, en la experimentación de acuerdos con representantes destacados del exilio y del interior, incluyendo a los monárquicos y excluyendo a los comunistas. Su propuesta para el restablecimiento de las libertades en Espańa era la celebración de un referéndum pactado sobre la forma de Estado, que debía contar con el apoyo de la comunidad internacional y ser convocado, preferiblemente, por un Gobierno sin signo institucional definido.

Esta línea política fue cobrando forma en varios discursos y escritos periodísticos de Indalecio Prieto en los órganos del partido y de la República. Uno de los discursos de mayor repercusión lo pronunció en el Teatro de la Comedia de la Habana el 13 julio de 1942 con el título «Propuesta de un plebiscito para resolver el caso de España». Su propuesta de celebración de un referéndum como única salida a la dictadura fue defendida con argumentos morales y emocionales que hablaban ya de la necesidad de procurar, en su opinión, una reconciliación entre todos los españoles: «Predico una política de unión, predico, cualesquiera que sean las críticas, una política de concordia» 
(Prieto, 1991: 159). Para favorecer esta concordia Prieto proponía renunciar a la petición de responsabilidades por los crímenes cometidos por la dictadura porque esa era, decía, la voluntad que le habían trasladado por carta distintos represaliados socialistas: «¿Sabéis lo que piden en ellas? Perdón para sus verdugos. Sabéis lo que proclaman: piedad, paz» (ibid:: 160). Atendiendo a estas declaraciones se entiende mejor la estima que Prieto ha merecido en la cultura política postransicional, en la medida que estos planteamientos prefiguraban el pacto político que se selló en la Transición y la propuesta de reconciliación que le sirvió de cobertura moral.

Lo más lejos que llegó Prieto en sus negociaciones con los monárquicos fue al conocido Pacto de San Juan de Luz, que finalmente quedó en papel mojado cuando los socialistas constataron que, al tiempo que negociaban con los representantes de don Juan, este sellaba su compromiso con Franco, acordando la educación de su hijo Juan Carlos bajo tutela del dictador. El pacto tampoco se vio favorecido por los confusos acuerdos que socialistas del interior estaban procurando por su cuenta, mucho menos exigentes. El golpe de gracia lo dio el cambio de corriente de fondo internacional en la que Prieto había cifrado sus expectativas: el incipiente contexto de la Guerra Fría en Occidente desaconsejaba la celebración de un referéndum donde fuera posible la reedición de una República de naturaleza progresista. Tras estos intentos Prieto terminó dimitiendo de la ejecutiva del PSOE en 1950 y reconociendo abiertamente su fracaso: «Mi fracaso es completo. Soy responsable de haber inducido a nuestro partido a fiarse de poderosos Gobiernos democráticos que no merecían esta confianza, como acaban de demostrarlo. Hice víctima a mi partido de una ilusión que me deslumbró». Si a pesar de su autorreconocido fracaso, la política de Prieto ha disfrutado en la cultura política de la Transición y la democracia de tan alta estima, ha sido también por las analogías que, en clave normalmente presentista, se han establecido entre su propuesta de acuerdo entre socialistas y monárquicos y el compromiso de los socialistas con la monarquía desde la transición a hoy.

Durante estos ańos Indalecio Prieto volvió una y otra vez a las causas que a su modo de ver provocaron la derrota de la República en la Guerra Civil, las mismas que según él motivaron su salida del Gobierno en 1938. De ello dejó constancia en la obra Cómo y por qué salí del Ministerio de Defensa Nacional. Intrigas de los rusos en España, publicada en 1939, que en realidad era, como figuraba en el subtítulo, un «texto taquigrafiado del informe pronunciado el 9 de agosto de 1938 ante el Comité Nacional del PSOE». Se trató de uno de los escritos de mayor repercusión en el exilio, que vino a reactivar las duras diatribas acerca del papel en la Guerra Civil de las distintas fuerzas políticas y que contribuyó a la construcción de un canon interpretativo que tendría amplio recorrido dentro y fuera del exilio, también en una historiografía de cuño 
conservador que sobrevive hasta hoy. Prieto cifraba el colapso interno de la República durante la Guerra en la influencia supuestamente abrasiva del comunismo nacional e internacional y en la complicidad para con ellas de un presidente, Negrín, hipotecado a la ayuda de la URSS. Según Prieto, la dependencia del comunismo habría repelido el respaldo de las potencias democráticas, habría inhibido el de los sectores intermedios y moderados de la sociedad y habría erosionado la moral de combate de los militantes adscritos a otras tradiciones políticas (Prieto, 1939: 9).

Durante sus años del exilio Prieto volvió a la Guerra Civil en multitud de escritos y discursos, varios de ellos publicados en 1954 bajo el título Entresijos de la Guerra de España (Intrigas de nazis, fascistas y comunistas). La obra da fe de cómo el anticomunismo gestado en la Guerra Civil se había cronificado en una parte del exilio y se había realimentado, además, de las tesis de la Guerra Fría que equiparaban comunismo y fascismo: «Las sospechosas connivencias [...] son más fáciles entre estalinianos y derechistas que entre soviéticos y demócratas porque estos últimos rechazan el principio inmoral de que el fin justifica los medios, principio común a los dos bandos antiliberales, quienes lo practican sin siquiera detenerse ante el asesinato» (Prieto, 1954: 8).

El ideario político de Prieto en el exilio quedó explicitado en otros discursos, como el pronunciado en el Círculo Pablo Iglesias de México el 1 de mayo de 1942, bajo el título "Confesiones y rectificaciones». En esta suerte de decálogo ideológico nociones clásicas del socialismo aparecían atravesadas por un fuerte vector liberal que el propio Indalecio Prieto reivindicaba expresamente: «Soy liberal, tan fervoroso partidario de las libertades individuales que llego a defenderlas, si me permitís una palabra exagerada, pero muy gráfica, hasta el salvajismo» (Prieto, 1975: 304). La impronta liberal se hacía más expresa al cifrar en el respeto a la gran propiedad privada las mayores esperanzas de progreso social: "Cierto que los teorizantes del socialismo predicaron siempre el respeto a la pequeńa propiedad [...], pero yo no me quedo ahí. La experiencia me dice que ese respeto ha de extenderse también a propiedades e industrias más vastas, pues no se debe luchar baldía y quizá desastrosamente contra afanes privados que son, al presente, el mayor acicate de progreso» (ibid: 309).

El socialismo del exilio experimentó una importante moderación práctica y también ideológica. No es de extrañar si se considera la influencia que siguieron ejerciendo sobre él algunos de sus principales referentes intelectuales de los años treinta, quienes ya entonces sostuvieron posiciones muy moderadas. Para entenderlo hay que tener en cuenta que la mayoría de los pocos intelectuales que se sumaron al PSOE a principios del xx no se habían formado dentro de tradiciones teóricas específicamente socialistas y marxistas del movimiento obrero, como sí lo hicieron por ejemplo los intelectuales del Partido 
Socialdemócrata Alemán (SPD), deudores de una amplia tradición de pensamiento eminentemente socialista, con figuras como Friederich Engels, Wilhelm Liebknecht, Eduard Bernstein o Karl Kautsky (Anderson, 2015:11-16). En España, por el contrario, la mayoría de los intelectuales socialistas vinieron del humanismo en su sentido más genérico, de la masonería y sobre todo del krausismo, del regeneracionismo y de la Institución Libre de Enseñanza (Juliá, 1997: 66-96). Quienes avanzados los años profundizaron en el marxismo y adoptaron posiciones abiertamente revolucionarias en los momentos más agitados de la Segunda República revisaron luego en el exilio estas posiciones a la luz de la experiencia traumática de la Guerra Civil, las tensiones de la Guerra Fría y el pacto social de postguerra, para volver a postulados análogos a los de partida. Entre quienes no se movieron mucho de esa formación inicial estarían, por ejemplo, Fernando de los Ríos y Luis Jiménez de Asúa. El caso paradigmático de quienes volvieron a ella después de un paréntesis izquierdista sería el de Luis Araquistáin. Sin embargo, entre estas dos trayectorias cabe hablar de un tercer socialismo, que ni procedía de posiciones tan temperadas ni terminó arribando a ellas, que tampoco participó del gran furor revolucionario de los años treinta y que en parte por eso no cargó contra ese ni contra otros furores revolucionarios posteriores. Hablamos de una tendencia de pensamiento minoritaria en el exilio bien representada por Max Aub. Veamos estas tres trayectorias intelectuales.

\section{LA CONSTANCIA DEL SOCIALISMO LIBERAL: FERNANDO DE LOS RÍOS Y LUIS JIMÉNEZ DE ASÚA}

Fernando de los Ríos es sin duda una de las figuras de mayor talla intelectual del socialismo español. Su fructífera carrera académica explica, en cierta medida, su compleja y temperada orientación ideológica dentro de la tradición socialista: fue alumno, primero, y profesor, más tarde, de la Institución Libre de Enseñanza; catedrático de la Universidad de Granada; rector de la Universidad de Madrid; y ya en el exilio profesor de la New School de Nueva York. Su contribución político-intelectual fue tanto más estimada en la medida que el socialismo español apenas había contado con intelectuales destacados en el ámbito del pensamiento político. Fernando de los Ríos se afilió al PSOE en 1919 y pronto desempeńó importantes cargos públicos: fue diputado en Cortes, ministro de Justicia en la Segunda República, embajador en Nueva York durante la Guerra Civil y ministro de Estado en el Gobierno en el exilio de José Giral (Ruiz Manjón, 2007). Su pensamiento político se vio modelado, lógicamente, por su experiencia política práctica. Entre los momentos que más le marcaron está, como él mismo narró, su viaje a la Rusia 
revolucionaria en 1920. En su conversación con Lenin — tantas veces citada en la historia política española - Fernando de los Ríos habría reafirmado la dimensión humanista y reformista de su socialismo, en oposición a un socialismo de cariz revolucionario proclive, en su opinión, al autoritarismo (De los Ríos, 1921).

Fernando de los Ríos escribió varios textos y dictó numerosas conferencias sobre temas muy diversos durante sus aproximadamente diez ańos en el exilio, varios de los cuales fueron compilados y publicados en 1956 por el intelectual cubano Raúl Roa con el título Ciencia y conciencia. Entre esos trabajos figura el interesante ciclo de conferencias pronunciadas en la Universidad de Morelia en junio de 1947.

En una de ellas, «Dualidad y comunidad», volvía a una de sus preocupaciones recurrentes: la de explicar al individuo en comunidad y la de procurar una relación de complementariedad entre la autonomía de aquel y las potencialidades de esta. En sus propias palabras: «Individualidad y comunidad, como fines esenciales, actúan no como algo que está completamente separado, sino coordinado: ni yo puedo concebirme ni explicarme a mí mismo, sino como órgano y elemento vivo de la comunidad; ni la comunidad puede ser explicada como una comunidad viva sin la cooperación que le presta a su vivir el individuo y los grupos sociales» (De los Ríos, 1974: 168).

En su conferencia indagaba en la formación de una idea coherente de libertad a cargo de autores como Tomás Moro, Luis Vives o el obispo de Michoacán Vasco de Quiroga. Tras realizar esta arqueología del pensamiento, o pese a ella, De los Ríos terminaba proponiendo una idea de libertad entendida como "garantía absoluta para la individualidad" y "plena seguridad de respeto para sus contenidos interiores», lo que obligaba a garantizar una fuerte «limitación del poder público» (ibid.: 166). Con ello basculaba hacia esa idea de "libertad negativa», de libertad entendida como defensa de la autonomía individual frente a la intervención de poderes colectivos o estatales que, como es sabido, desarrollaría y propugnaría unos años después Isaiah Berlin (2005), pero que tan en boga estaba ya en ese contexto de Guerra Fría, sobre todo en las universidades estadounidenses en las que De los Ríos impartía clase.

En cualquier caso, su pulsión socialdemócrata le llevaba a insistir en la importancia de los poderes públicos a la hora de generar las condiciones necesarias para el desarrollo de esta libertad y autonomía individual por medio de la creación de unas bases mínimas de bienestar material y el freno al dominio excesivo de unos grupos sobre otros. A reflexionar sobre la generación de estas condiciones materiales dedicó las siguientes conferencias sobre economía política: "Capitalismo y Capitalización», "La existencia del salario y el proceso de capitalización» o «Estructura de las empresas de 
carácter público». En ellas analizaba parte del marco categorial construido por Smith, Ricardo y Marx para aplicarlo a los procesos económicos de España y México (De los Ríos, 1974).

En 1951, poco después de su muerte, se publicó una de las obras más importantes de Fernando de los Ríos: ¿A dónde va el Estado? Estudios filosófico-políticos. La obra es un recorrido erudito y penetrante por la teoría del Estado, cuya finalidad, así reconocida por el propio De los Ríos, era promover una mejor comprensión de las distintas formas de Estado en la década de los cuarenta, particularmente del Estado nazi. El análisis del nazifascismo fue una de las principales preocupaciones de los intelectuales republicanos durante los primeros años el exilio, que De los Ríos abordó también en conferencias impartidas en la Universidad de La Habana en 1941 y en la Universidad de Puerto Rico en 1943 (Sánchez Cuervo, 2017).

Sus análisis suponen una aportación original al estudio del nazifascismo, donde, más allá de sus causas inmediatas, el nazismo se explica a partir de importantes corrientes culturales de fondo. Los antecedentes más remotos los situaba en algunas ideas de los principales filósofos políticos de la modernidad, como Maquivelo, Bodino, Grocio y Hobbes: en la centralidad de la noción de soberanía y en la reivindicación de mayor poder para el Estado. El nazismo representaría un desbordamiento del poder reivindicado para el moderno Leviatán y una exacerbación de la racionalidad violenta que lo soporta. Otro antecedente teórico-político lo situaba en los Discursos a la nación alemana de Fichte, donde esta era entendida como una comunidad natural arraigada objetiva y emotivamente en las nociones de lengua, cultura y raza; una comunidad, en opinión del filósofo alemán, con necesidades objetivas de ampliación territorial y una legítima aspiración a universalizarse. En palabras de Fernando de los Ríos, «Alemania a los ojos de Fichte tenía una misión: moderar, coordinar, equilibrar la Europa continental. Pero el patriota va empujando al cosmopolita [...]. La divisa es: ¡Por la educación nacional a la salvación de Alemania y de la raza!» (De los Ríos, 1951: 149).

Según de los Ríos, la sistematización racional de estas aspiraciones nacionales correspondería a Hegel, que terminó identificándolas con el despliegue dialéctico de una razón universal que vendría a objetivarse en el Estado, una objetivación que luego Hitler asociaría al III Reich. Para procurar ese salto el nazismo tuvo que recurrir a otras muchas ideas, entre las cuales Fernando de los Ríos citaba la voluntad de poder nietzschiana, las teorías de la superioridad racial aria de Joseph Arthur de Gobineau, el mito movilizador del sindicalismo revolucionario e irracionalista de Georges Sorel, el elitismo que late bajo la teoría de la circulación de las élites de Pareto o, finalmente, la distinción amigo/enemigo propugnada por Carl Smith. En opinión de Fernando de los 
Ríos, de algunas de estas ideas solo podía derivarse la tragedia: «C. Schmitt pone el acento en "el otro", en el enemigo, en el prójimo, al cual, en caso de conflicto, hay que aniquilar» (ibid.: 289).

El libro contenía momentos lúcidos e irónicos, como el paralelismo que De los Ríos trazaba entre el mito judío del destino absoluto del pueblo elegido y el mito nazi del destino universal de la raza aria superior:

Por una ironía de la historia, el tercer Reich con esta que consideraba misión suya - destruir al pueblo judío del que se había declarado enemigo irreconciliable-, incurrió en el mismo error trágico en que, de creer a algunos historiadores, hubo de incurrir el pueblo de Israel: el de idolizar una situación efímera; el de pensar que, puesto que había sido capaz de alcanzar en la época de los profetas una alta cima en la vida del espíritu, era, en cuanto a comunidad el pueblo elegido, cayendo así en el pecado de idolatría de su yo colectivo, pecado el más apto - decían precisamente los hebreos - para atraer la venganza de un Dios celoso (ibid.: 298 y 299).

El análisis de la terrible experiencia del nazifascismo y la prolongación de la dictadura en España reforzaron en estos intelectuales del PSOE el valor concedido a las libertades públicas e individuales y la veta liberal que ya traían en su acervo. Este también fue el caso de Luis Jiménez de Asúa, eminente jurista ya antes de la llegada de la República, que pasó la mayor parte de su exilio en Buenos Aires. Jiménez de Asúa fue autor durante el exilio de cuantiosos prólogos, epílogos y conferencias donde exaltaba la idea de libertad y abogaba por un socialismo muy contenido en el marco de una democracia liberal de sesgo antiestatalista. De su texto Ante España. El PSOE, la democracia, la Ley y la Universidad (1955) cabe entresacar como ejemplo de lo primero la siguiente consideración: «La libertad y el derecho a la disidencia son los signos por los que se reconoce la democracia auténtica. Todo el que tenga miedo a la libertad no está seguro de la legitimidad de sus poderes» (ibid:: 6). Como ejemplo de lo segundo cabe citar: «La democracia es el mínimo de intervención estatal en la existencia del individuo, si solo queremos referirnos al momento presente. El mínimo necesario, lo que no quiere decir, por tanto, que el ideal consista en abolirlo» (ibid.: 7-8).

Por otra parte, en sus trabajos jurídicos conjugaba esta perspectiva con la histórica y la politológica. Un ejemplo de ello lo tenemos en La Constitución política de la democracia española (1942), donde analizaba la Constitución republicana de 1931 atendiendo al contexto histórico, a los debates parlamentarios, a algunas contribuciones personales y a los valores y corrientes teóricas que la inspiraron. 


\section{LUIS ARAQUISTÁIN: DEL SOCIALISMO REVOLUCIONARIO AL CRUDO POSIBILISMO}

Luis Araquistáin siguió siendo uno de los intelectuales más destacados del PSOE, aunque en posiciones muy distintas de las que sostuvo en los años treinta. Su trayectoria antes del exilio es bien conocida. Ingresó en el PSOE en 1911, fue diputado en Cortes y subsecretario del Ministerio de Trabajo durante la República y en la guerra ocupó el puesto de embajador en Berlín y París durante el Gobierno de Largo Caballero. Araquistáin fue director de importantes periódicos y revistas, como España, Claridad y Leviatán, esta última fundada por él mismo en 1934 para servir a la reflexión teórica del socialismo español, tan necesitado entonces de ella. El nombre de la revista - una clara referencia a la obra de Hobbes- representaba su apuesta por la creación de un poderoso Estado como forma institucional de la dictadura del proletariado; un Estado que, una vez hubiera desplegado las medidas coactivas conducentes a la transformación socialista de la realidad, debería autofagotizarse para dejar tras de sí una sociedad de hombres libres e iguales capaz de autorregularse. El Leviatán de Araquistáin confrontaba abiertamente con el Caballo de Troya que Julián Besteiro propugnaba como metáfora para construir el socialismo dentro de la institucionalidad liberal. El monstruo del uno frente al artificio del otro expresaban en cierta medida la confrontación de planteamientos y talantes dentro del socialismo anterior a la Guerra Civil. La producción intelectual de Araquistáin y las posiciones que mantuvo dentro del PSOE le convirtieron, o así fue percibido, en el intelectual orgánico del caballerismo, considerado el sector marxista y revolucionario del partido.

Al final de la Guerra Civil y más nítidamente en el exilio Araquistáin decidió hacer, en sus propias palabras, "borrón y cuenta nueva» (Fuentes: $2002,23)$ de esa etapa revolucionaria. El giro se debió al precio de la derrota en la Guerra Civil española, especialmente oneroso para el caballerismo, así como a la conciencia temprana de que la dinámica geopolítica bipolar, en virtud de la cual las potencias occidentales nunca intervendrían contra Franco, alejaba remotamente el horizonte del socialismo para España. Ambas experiencias le hicieron bascular entre los polos complementarios del fatalismo y el pragmatismo. A esta moderación tan acusada contribuyó también una revisión más tranquila de la tradición filosófica, sobre todo socialista, en el tiempo calmo del exilio. Ese tiempo prolongado permitió que sedimentara una personalidad ya de antes inclinada al individualismo, la reflexión solitaria y cierto nihilismo antropológico, si nos atenemos al relato autobiográfico bien documentado de Juan Francisco Fuentes (2002).

La ruptura con las tesis revolucionarias que había sostenido hasta hacía pocos años derivó en una marcada hostilidad hacia quienes siguieron 
defendiéndolas y en un anticomunismo visceral alimentado por la amarga memoria de los conflictos con el PCE al final de la contienda, ahora espoleada por los discursos de la Guerra Fría. El Congreso por la Libertad de la Cultura, un organismo de propaganda financiado por la CIA (Glondys, 2012), aprovechó este marcado anticomunismo nombrándole al final de su vida director de la revista Cuadernos (Fuentes, 2002: 17) y publicando algunas de sus diatribas contra el papel de los comunistas en España, como La intervención de Rusia en la Guerra Civil española (1958) o Franco y el comunismo (1959).

En contacto frecuente con Julián Gorkin y Salvador de Madariaga -auténticos puentes entre el exilio y las redes culturales de la Guerra Fría al servicio de la "causa de Occidente»— Luis Araquistáin desempeñó una labor importante en la edición y promoción de autores y trabajos ${ }^{2}$. La historia del pensamiento político en el exilio debería poner más énfasis en estas relaciones, pues las ideas del exilio se fueron conformando y abriendo paso no solo por su originalidad, potencia o capacidad para expresar un anhelo colectivo. También en virtud de las complejas influencias entre autores que mantenían relaciones a veces fundadas en una amistad o afinidad más o menos trasparentes, y otras marcadas por la dependencia, el intercambio de favores o la trasferencia de capitales simbólicos. También en virtud de una institucionalidad constituida por encuentros, congresos, revistas o editoriales que, en función de su potencia para publicar, difundir y reconocer en el espacio público los trabajos intelectuales, condicionaba su tono y su contenido, tanto más en una situación tan precaria como la del exilio. Reconstruir estas redes por medio de los enfoques de la sociografía, la prosopografía o la sociología del conocimiento puede abrir nuevas vías de comprensión de la historia del pensamiento político en el exilio.

Durante el exilio Araquistáin propugnó la reconciliación de los españoles divididos por la Guerra Civil y destinó algunos de sus trabajos a fundamentarla teóricamente. En su ensayo La idea sociológica del Estado (1953) hacía un recorrido por la historia de España a partir del conocido esquema dialéctico hegeliano de la tesis, la antítesis y la síntesis, para reclamar una España reconciliada por medio de una combinación de intereses (la síntesis) entre quienes habían logrado imponerlos violentamente (la tesis) y quienes aspiraban a recuperar sus derechos por la vía reformista o insurreccional (la antítesis). Es evidente que en el esquema de Araquistáin estos últimos eran los republicanos

Así se comprueba cuando se accede a la amplia correspondencia mantenida entre los tres contenida en el Archivo de Particulares de la Fundación Pablo Iglesias. Véase por ejemplo el cruce frecuente de cartas entre Araquistáin y Gorkin en AJGG557-12 y ALA99-1. 
derrotados, mientras que el franquismo representaba ese «estado primitivo de conquista» que, habiéndose desplegado por medio del militarismo durante los siglos XIX y XX, hundía sus raíces en una España medieval donde la espada, ya fuera árabe ya cristiana, había constituido la razón última de Estado. Más que historiar este devenir histórico conflictivo, Araquistáin venía a naturalizarlo y a ofrecer, como única alternativa a ese "estado primitivo de conquista», «un estado civil» que por medio del acuerdo con todos pudiera dar lugar al surgimiento de una auténtica "comunidad nacional».

La visión de Araquistáin de las relaciones internaciones fue extremadamente posibilista. Las interpretaba como resultado de la primacía de los intereses de Estado y del más puro egoísmo nacional, factores que, en su opinión, siempre prevalecían frente a las afinidades ideológicas que pudieran sentir unos países hacia otros. Tan crudo análisis le permitió aventurar tempranamente que las potencias occidentales no intervendrían contra Franco porque les supondría más riesgo y esfuerzos que beneficios. También le llevó a proponer al Gobierno republicano en el exilio que hiciera de idéntico interés y egoísmo su política de Estado. En su opinión, el Gobierno en el exilio debería ofrecer a Estados Unidos la misma lealtad incondicional que Franco le había brindado, ofreciéndole un capital simbólico añadido que apaciguase su conciencia: la condición democrática de la República (Fuentes, 2002: 219-222).

Con los años, Araquistáin se fue distanciando de las tesis oficiales del Gobierno del exilio que reivindicaban la restauración de la legitimidad republicana. Al final rompió también con las propuestas de su propio partido, que reclamaban la celebración de un referéndum sobre la forma de Estado como mejor salida a la dictadura. Araquistáin defendió un documento en el VII Congreso del PSOE en el exilio de 1958, titulado La táctica del Partido Socialista Obrero Español y los acuerdos de París, donde apostaba por la aceptación de una monarquía no refrendada electoralmente como vía más plausible para la recuperación de la democracia en España. Para justificar esa apuesta Araquistáin realizaba un recorrido por la tradición accidentalista del PSOE a propósito de la forma de Estado. En el texto denunciaba el mal trato que a su juicio recibieron las organizaciones socialistas de manos de la Primera República; aplaudía la decisión de Pablo Iglesias de participar en las instituciones de la Restauración; celebraba el poco énfasis que el fundador del PSOE puso en la cuestión republicana; y valoraba positivamente como ejemplo de pragmatismo a seguir la participación del PSOE en el Gobierno de Primo de Rivera (Araquistáin, 1983: 327-345).

Los trabajos de Araquistáin en el exilio ponen de manifiesto su negativa a concebir la política como reivindicación de principios abstractos o formas políticas puras. Entendía el socialismo como un proceso acumulativo de derechos políticos y mejoras sociales concretas sin destino último ni forma institucional 
definida. Así, denunció la defensa incondicionada de la República como una forma de «fetichismo de la forma de gobierno» (ibid:: 334). En su oposición a la defensa incondicional de la República latía también el viejo desprecio de sus años de radicalismo revolucionario hacia los partidos republicanos. Si antes criticaba la obstinación de la izquierda por la defensa de lo que a su juicio era un formalismo institucional pequeñoburgués desprovisto de contenidos políticos y sociales, en el exilio reclamará la aceptación de la monarquía en España como mejor camino para poder luchar de nuevo por esos contenidos.

El pensamiento español contemporáneo, publicada póstumamente en 1962, es una de las obras más interesantes de Araquistáin. En el recorrido que realiza por algunas figuras de la historia del pensamiento español van cobrando forma sus propios presupuestos políticos y filosóficos. En este ensayo Ortega y Gasset merece un juicio igualmente crítico al que Araquistáin hizo sobre el filósofo en sus escritos de juventud, aunque ahora expresado en un tono menos vehemente. Araquistáin atribuía de nuevo a Ortega una cierta responsabilidad en la instrumentalización que de él hizo el fascismo, del mismo modo, nos cuenta, que atribuía a Nietzsche cierta responsabilidad en la posterior instrumentalización que de él hizo el nazismo. Para Araquistáin, Ortega no era solo un liberal doctrinario, era el defensor de un elitismo antidemocrático que, aunque en contra de su propia voluntad, iba a encontrar lógicamente buena acogida en el fascismo español. Para mayor escarnio de Ortega, decía Araquistáin, el fascismo español seleccionó a sus élites de entre lo peor de la sociedad (Araquistáin, 1962: 80-92). En el libro Araquistáin cargaba también contra las filosofías idealistas y pacifistas de entreguerras, en concreto contra el krausismo. Las responsabilizaba de haber creado un clima intelectual e ideológico hostil a un acuerdo militar con Francia a comienzos de los treinta que luego podría haber garantizado la intervención de la potencia gala en auxilio de la República. Según Araquistáin, eran esas mismas convicciones idealistas y pacifistas las que en el nuevo contexto de la Guerra Fría estaban alimentando una política equidistante muy funcional para el imperialismo soviético. Esa crítica al pacifismo y la equidistancia la hacía extensible a quienes en la Guerra Civil se habían reclamado miembros de una tercera España (ibid.: cap. II).

No mejor valoración le merecía toda la tradición de pensamiento mística y teológica española, de la que, en su opinión, habría arrancado un tipo de filosofía necrófila continuada luego por pensadores como Miguel de Unamuno, cuya obsesión por la muerte suponía un lastre para la vida (ibid:: 67-86). La sorpresa que produce la buena opinión que Araquistáin tenía de Menéndez Pelayo se atenúa cuando se comprueba que esta opinión se reducía a su estudio sobre los heterodoxos de la historia de Espańa (ibid.: 40-53). Entre las figuras más veneradas por Araquistáin estaba Joaquín Costa, del que subrayaba su crítica al caciquismo y la oligarquía. También su llamamiento en pro de un proyecto científico, técnico 
e industrializador que sacara a España de su atraso; algo muy alejado del krausismo y el institucionismo, para quienes el motor del progreso sería una educación humanista y moralizante. De Joaquín Costa reivindicaba, incluso, su polémica idea del «cirujano de hierro», sugiriendo la necesidad de un régimen presidencialista para la futura democracia española (ibid.: 50-61).

Si se observa la trayectoria completa de Araquistáin, hay que matizar la idea de su acusado giro en el exilio. Sus bases filosóficas, tendencias intelectuales y gustos culturales son más constantes en su trayectoria que las cambiantes posiciones políticas que a lo largo de su vida justificó con buena parte de ese mismo acervo. Entre esas constantes está, por ejemplo, su identificación con la tradición regeneracionista española, la consideración del socialismo como un humanismo, la reivindicación de la ética como fundamentación de la política bajo la inspiración del neokantismo de Cohen y la desconfianza que siempre le merecieron la tradición republicana y krausista (Rivera, 2009). Pese a esos elementos constantes no deja de resultar evidente el marcado contraste entre el furibundo revolucionario marxista de la República y el pragmático partidario (aunque fuera accidental) de la monarquía y la OTAN del exilio.

De la Transición en adelante la figura de Araquistáin ha sido objeto de una reestimación considerable en importantes espacios académicos y culturales, así como en buena parte del socialismo español. Además del notable interés de sus aportaciones, otra de las razones fundamentales está en su peculiar trayectoria. Su anclaje de partida en el humanismo y el neokantismo, el extenso e intenso paréntesis revolucionario de este pensador durante la Segunda República y la Guerra Civil y su profunda autorrevisión en el exilio, hasta reubicarse definitivamente en una posición socialdemócrata con una fuerte impronta liberal, resultaban atractivos para una parte importante de una generación de intelectuales y socialistas, la de la Transición, que, mutatis mutandi, experimentó una evolución en cierta medida análoga: acceso inicial a corrientes humanistas a través de cristianismo social o las universidades de la dictadura, radicalización en el contexto sesentayochista de la oposición y contención y reajuste ideológico al ritmo de la Transición y el acceso al Gobierno. En las posiciones de Araquistáin en el exilio podían encontrarse además tres ejes que, en términos también análogos, han vertebrado la política del PSOE del último tramo de la Transición a hoy: reconciliación nacional, atlantismo y accidentalismo monárquico.

\section{LEALTAD REPUBLICANA Y ALTERNATIVA A LA BIPOLARIDAD: MAX AUB}

En la periferia de la tradición socialista del exilio se movió el dramaturgo, poeta, novelista y ensayista Max Aub, ya fuera por su inclinación a la heterodoxia 
ya fuera por la marginación que sufrió de sus viejos compañeros de partido. Max Aub se afilió al PSOE en 1927, probablemente por mediación de Luis Araquistáin (Aznar Soler, 2003: 17 y 18). La relación entre Aub y Araquistáin es digna de mención porque los viejos amigos diseñaron trayectorias políticas y militantes no solo distintas sino opuestas. Si Araquistáin pasó de un socialismo marcadamente revolucionario de proclamada fe marxista a un socialismo pragmático de pronunciado sesgo liberal y anticomunista, Max Aub se movió siempre dentro de los parámetros de un socialismo democrático que pretendía conjugar la economía socialista con las formas políticas liberales. Su apuesta literal era por «una economía socialista en un Estado liberal». En su concepción la libertad solo podía existir entre iguales y la economía debía «estar en manos del Estado, o perfectamente controlada por él». (Aub, 1967: 51).

Para Max Aub la equiparación entre fascismo y comunismo soviético, tan frecuente por ejemplo en Araquistáin, no tenía ningún sentido. En su ensayo El falso dilema, publicado por primera vez en prensa en 1949, Aub despreciaba tal equiparación de manera rotunda: «No caeré en la tontería de asegurar, como lo hacen algunos que no quieren tomarse el trabajo de enterarse, que el comunismo soviético corresponde a cierta forma de fascismo, ni tampoco que lo sea el imperialismo norteamericano» (ibid.: 45).

Durante la Guerra Civil, Aub fue agregado cultural en la embajada de Espańa en París, organizó el II Congreso Internacional de Escritores para la Defensa de la Cultura o desempeñó el cargo de secretario del Comité Central del Teatro. Cuando partió al exilio sufrió las terribles penurias de los campos de concentración del sur de Francia y Argelia hasta que finalmente logró salir para México, donde vivió, trabajó y militó hasta su muerte en 1972. Su militancia se desarrolló siempre dentro de la tradición socialista, pero no siempre dentro de las filas del PSOE, pues en abril de 1946 fue expulsado del partido junto a Juan Negrín; el antiguo secretario general del partido, Ramón Lamoneda; y el anterior presidente de la Comisión Ejecutiva, Ramón González Peña. Sin perjuicio de la originalidad de una obra marcadamente personal, participó de ciertos aspectos de esta suerte de cultura política en el exilio (De Hoyos, 2016) que fue el negrinismo.

Como todo pensamiento político, el de Max Aub es producto de sus experiencias vitales y militantes, pero en su caso es también el resultado de su voluntad de pensar más allá de su propia experiencia personal. Solo desde esta voluntad y honestidad intelectual se entiende su capacidad para no sucumbir al anticomunismo cultural de la época, cuando tuvo razones personales para ello habida cuenta de los ataques que en el exilio recibió de destacados intelectuales y hasta amigos del PCE como respuesta a la sátira a cierta militancia comunista que hizo en su cuento Librada (1948). Desde esta voluntad se explica también que no se echara en brazos del comunismo cuando en esa 
dirección le empujaron algunos viejos compañeros PSOE al tacharle despectivamente de filocomunista o al delatarle falsamente como militante comunista nada más salir de Espańa (Aznar Soler, 2003: 49-67).

Entre los aspectos más originales de los escritos expresamente políticos de Max Aub está la crítica a la lógica bipolar de la Guerra Fría y a las repercusiones que esta tuvo en el mundo de la cultura. Bajo el título Hablo como hombre se publicaron en 1967 varios textos sobre este y otros temas.

En el breve ensayo Bases norteamericanas en España, publicado originalmente en 1951, Max Aub denunciaba que la supeditación a los intereses imperialistas de Estados Unidos había homogeneizado a los dos grandes partidos del turnismo estadounidense. También denunciaba una realidad cada vez mejor documentada por la historiografía (Fontana, 2011), aunque todavía contradicha por la cultura de masas: que la política exterior norteamericana en la Guerra Fría fue más agresiva que la soviética. En estos términos lo expresaba Max Aub en 1951: «Las bases que retienen los Estados Unidos alrededor de Rusia hubiesen echado para adelante los ejércitos de cualquier nación en tiempos pasados. La URSS aguanta toda clase de provocaciones no oponiendo sino protestas verbales y guardándose muy bien de exacerbar directamente a su poderoso rival» (Aub, 1967: 68).

En el ensayo, Aub captaba tempranamente algunas de las lógicas de la Guerra Fría, constataba la precariedad de los equilibrios construidos y pronosticaba su difícil resolución. Para Aub la capacidad militar de ambas potencias y el grado de destrucción mutua que generaría un enfrentamiento abierto impedían el triunfo territorial de cualquier bando sobre el otro. Con ello planteaba una contradicción irresoluble que más tarde el gran intelectual conservador Raymond Aron calificó de "guerra improbable, paz imposible». Pese a esta realidad, planteaba Max Aub, ambas potencias estaban interesadas en invocar constantemente la posibilidad de una guerra abierta. Los Estados Unidos para mayor beneficio de su industria armamentística. En ambos casos porque apelar al miedo a una guerra servía para «consolidar los dos regímenes que la fomentan» (ibid.: 70). En este ensayo de 1951, Aub acertaba a la hora de anticipar las consecuencias a corto y medio plazo que traería esa dinámica de confrontación bipolar: «La producción bélica irá en aumento, las precauciones policiacas no se quedarán a la zaga, en espera de que la ciencia llegue a poner en su punto armas lo suficientemente mortíferas para acabar, si no de una vez, de varias con la mitad del género humano; lo que no parece cosa de mañana, aunque si de pasado» (ibid.).

En su ensayo El centenario de Goethe y la Guerra Fría, publicado originalmente en 1949, Aub criticaba las dinámicas culturales, excluyentes y empobrecedoras, que la Guerra Fría había generado al fijar una artificiosa división cultural entre Oriente y Occidente basada en el desconocimiento mutuo 
(ibid:: 32). De igual modo, en su escrito de 1949 al profesor y editor Roy Temple House de la University of Oklahoma arremetía contra semejante división y denunciaba los mecanismos de censura y exclusión que se daban en ambos ecosistemas culturales:

Creo, como es natural, en la identidad de la cultura, y nada me parece más despreciable que los que pretendan dividirla en oriental y occidental [...]. El intelectual comunista no puede decidir por sí; el partido le suministra, son palabras de un teórico del mismo, una concepción científica armónica de la vida. Por otra parte, en los Estados Unidos si un escritor pugna por cambiar la actual estructura del Estado, tiene el peligro de acabar en la cárcel (ibid.: 40).

En El falso dilema Max Aub denunciaba las estrechas similitudes entre las dos superpotencias en sus aspiraciones y formas de obrar a nivel internacional. En oposición a esa dinámica de alineamiento en torno a dos polos excluyentes Max Aub señalaba una alternativa para desarrollar, que más tarde otros intelectuales y políticos calificarán de «tercera vía», pero que para Aub representaba realmente una cuarta, pues para él la tercera posición, también descartable, se concretaba en los intentos mediadores de la Iglesia Católica. Según Max Aub había que salirse del "falso dilema» consistente en elegir entre el bloque soviético y el estadounidense y apostar por el fortalecimiento de «un área digna de tener en cuenta, donde no predominan, todavía decisivamente, ninguna de las dos fuerzas por hoy antagónicas» (ibid.: 49).

La oposición de Max Aub a cualquiera de los dos bloques se debía al rechazo que le generaban sendos modelos de sociedad, así como a la forma avasalladora de concebir las relaciones internacionales por ambas superpotencias. Pero se debía también a algo más, a un sentido fuerte de la soberanía y la dignidad nacional, tanto más intenso en la medida que se trataba de la soberanía y la dignidad de un país, la España republicana, que en la Guerra Civil había dado un ejemplo al mundo defendiendo hasta la muerte un proyecto de sociedad y una forma de inserción en la comunidad de naciones mejores y alternativos a los que ahora representaban Estados Unidos y la URSS. Para Max Aub la causa republicana en el exilio representaba un capital de dignidad que no se podía dilapidar por medio del vasallaje a ninguna potencia extranjera con afán imperialista. Sus palabras al respecto fueron contundentes:

El solo hecho de tener que escoger entre dos soluciones extranjeras, la rusa y la norteamericana $[\ldots]$ demuestra un sentimiento de reverencia a cualquiera de estas potencias. España ha dado demasiado de sí, en tiempos pasados y presentes, y hoy, desparramada en una diáspora como no la hay precedente, para venir a uncirse al carro del más fuerte [...]. La palabra España, sin más, en sí, bastaría, 
para no adscribirse a ningún bando, cuando estos convierten nuestra patria en peón de su juego (ibid.: 47 y 48).

A este respecto resultan llamativas no solo las diferentes posiciones, sino las formas antagónicas de argumentación sobre un mismo tema de Araquistáin y Aub. Si el pragmatismo descarnado del primero le llevaba a propugnar una adhesión incondicional de España a Estados Unidos, el sentido patriótico de Aub le conducía a no adherirse a ninguno de los bandos. Si Araquistáin exponía sus argumentos en términos políticos restrictivos —aquellos que se reducen al cálculo y el interés en el marco de las crudas relaciones de poder-, el segundo los expresaba en términos fundamentalmente éticos - aquellos que fijan una posición política en función de su ajuste a unos valores-

\section{EL PSOE EN FRANCIA: MODERACIÓN Y EUROPEIZACIÓN}

Ante el repliegue definitivo de Indalecio Prieto a comienzo de los cincuenta, la dirección política del PSOE pasó definitivamente al grupo de Toulouse encabezado por Rodolfo Llopis. A lo largo de estos años el PSOE experimentó un proceso de considerable moderación ideológica, que coexistió con algunos residuos entreverados de la vieja retórica maximalista. En cualquier caso, la apuesta por la transformación revolucionaria de la sociedad a partir de la conquista del poder político por parte del proletariado — según la vía que pudiera resultar más adecuada en cada momento- cedió a la aceptación completa de la democracia liberal como fin en sí mismo y marco desde el cual promover las reformas orientadas a una mayor igualdad social.

Este intenso giro a la moderación se debió a la influencia de los intelectuales arriba analizados, aquellos, sin duda, más destacados y de mayor capital simbólico dentro del partido, pero también a otros factores de peso. Entre ellos, a una relectura de la compleja experiencia de la revolución social que se desató al comienzo de la Guerra Civil. Como es sabido, con el estallido de la contienda se desarrolló un proceso revolucionario en España de fuerte sesgo sindical y amplio protagonismo de las bases socialistas. Poco después fueron dirigentes socialistas, con Largo Caballero a la cabeza, quienes, en virtud de su autoridad sobre la UGT, lograron frenar ese proceso revolucionario al objeto de restablecer el orden republicano como mejor marco para afrontar la guerra. Esa misma política fue desarrollada más intensamente por Juan Negrín en alianza con el PCE, el heredero directo de la revolución bolchevique, que en esos momentos, sin embargo, estaba plenamente comprometido con las instituciones republicanas. Durante los dos Gobiernos las bases socialistas bascularon entre el respaldo a la disciplina gubernamental y la ańoranza de la 
revolución, en función muchas veces de la posición que al respecto ocuparon sus aliados y competidores. Por todo ello, el PSOE salió de su contacto real con una revolución contenida y al final derrotada demasiado contrariado, agotado, desencantado o escarmentado como para que esta pudiera seguir ocupando, aunque fuera a nivel teórico, un lugar central en el pensamiento político de sus intelectuales y dirigentes, incluso de los situados más a la izquierda. Por otro lado, buena parte de los esfuerzos políticos e intelectuales de los socialistas del exilio se orientaron a esbozar posibles salidas a la dictadura en España. Como es lógico, la revolución se fue disipando de su horizonte teórico en la medida que desbordaba con creces las posibilidades del momento, pensadas y vividas con tal intensidad que en ellas se agotaba muchas veces todo ejercicio intelectual.

Hay otro vector contextual muy influyente en este giro del PSOE del exilio. Remite al proceso de crecimiento económico y construcción del Estado de bienestar en la Europa de los años cincuenta y sesenta; es decir, a las condiciones políticas, culturales y socioeconómicas en que se produjo buena parte del pensamiento socialista del exilio y se estabilizó la que sería, hasta la Transición, su orientación política. Se trató de un proceso que afectó a todos los partidos socialdemócratas europeos en un sentido muy parecido: el de procurar una reconciliación más o menos explicitada con el capitalismo como modelo para la generación de crecimiento económico y una reconceptualización del socialismo como procedimiento estatal para la redistribución de sus beneficios. Ese giro ideológico fue, en gran medida, la expresión doctrinaria, dentro de la socialdemocracia, del gran pacto social de postguerra en la llamada «edad de oro» del capitalismo.

El desvanecimiento del horizonte de transformación socialista de la economía por parte de la socialdemocracia europea hundió sus raíces en los logros de un capitalismo con fuertes correctivos sociales durante esa etapa que llega hasta el 68 y se prolonga, renqueante, hasta el 73. Este capitalismo - verbalizado de forma un tanto exagerada como economía mixta o economía social de mercado - disfrutó de una amplia legitimidad popular que los partidos socialdemócratas con voluntad de acceso rápido al gobierno no podían ignorar. Los años cincuenta conocieron un intenso crecimiento económico, basado en el incremento de la productividad por efecto de la innovación tecnológica, en la financiación estadounidense, en la explotación de una mano de obrera flexible procedente de distintas migraciones o en la ampliación internacional de los mercados, pero también en el aumento de la inversión pública y el incremento de la demanda nacional de acuerdo a unos parámetros económicos de inspiración keynesiana que fueron trasversales a partidos de distinto signo ideológico. Causa y consecuencia de este modelo de crecimiento fue el incremento de los salarios, lo que permitió un acceso masivo a bienes de consumo de 
distinto tipo, que abrieron la senda a nuevas formas de vida, de ocio y de distinción social. La necesidad de estabilidad del modelo y la relación de fuerzas sociales hicieron que los excedentes de este crecimiento, obtenidos generalmente por vía fiscal, fueran utilizados para poner en marcha un amplio estado asistencial que mejoró las condiciones de vida de una parte importante de las clases populares (Hobsbawm, 1998: 260-289).

La potencia de estos cambios múltiples, el respaldo que merecieron de una amplia base social y el escaso atractivo que tenía el modelo alternativo del socialismo real están en la base de este nuevo giro moderado de la socialdemocracia. Sobre esta base se articularon otros factores que redundaron en beneficio del reajuste ideológico: estrategias electorales, cambio en la composición sociológica de los partidos, profesionalización de sus dirigentes, etc. En cualquier caso, el giro tuvo dos de sus expresiones doctrinarias más elocuentes allí donde estos fenómenos socioeconómicos habían arraigado hondo y donde la socialdemocracia, siendo particularmente fuerte, tenía serias dificultades para llegar al Gobierno: en Reino Unido y en Alemania. En Reino Unido se publicó, por ejemplo, The Furture of Socialism (1956), de Anthony Crosland, un libro extraordinariamente influyente que sintetizaba las aportaciones del ala moderada del laborismo nucleada en torno al periódico Socialist Commentary. En Alemania tuvo lugar en 1959 el famoso congreso del SPD en Bad Godesberg, en cuyo programa se oficializaron y enfatizaron cambios estratégicos e ideológicos que ya se venían incorporando para hacer más atractiva la imagen del partido. En ambos documentos se explicitaron las líneas básicas que en la práctica asumió la mayor parte de la socialdemocracia europea: identificación plena con las instituciones liberal-parlamentarias, compromiso con el atlantismo, aceptación del capitalismo como marco económico para la generación de la riqueza a distribuir, defensa en general de la propiedad privada de los medios de producción y contención del programa de nacionalizaciones, énfasis en el Estado de bienestar y el acceso al consumo, proyección hacia una base social amplia e interclasista y fin definitivo de la idea de socialismo como momento de ruptura o salto histórico (Sassoon, 2001: 276-289).

Este fue el contexto ideológico dominante en la socialdemocracia europea que servía de referencia a todos los partidos socialistas del mundo, tanto más a aquellos como el PSOE que, por la dispersión de sus dirigentes e intelectuales en el exilio, más dependían ideológica, organizativa y financieramente de ella. Y esta también es una de las claves para entender la evolución doctrinaria y la producción de pensamiento político del socialismo español en el exilio. De un lado, el hecho de que buena parte de sus dirigentes e intelectuales pensaran desde su inserción política y vital en los países europeos de la «edad de oro del capitalismo», donde el pacto social de postguerra generaba avances sociales que estaban experimentando en su cotidianidad. De otro, el 
hecho complementario de que, desubicados y dispersos territorialmente, estos dirigentes pensaran e idearan en el marco de una relación orgánica, en cierta medida de dependencia, con las formaciones socialdemócratas europeas.

En virtud de ambas cosas cabe hablar de un proceso de europeización del PSOE durante el exilio en al menos dos sentidos. Por una parte, en el sentido de su equiparación a los parámetros de la socialdemocracia europea, sobre todo de la socialdemocracia francesa de la SFIO. Por otra parte, en el sentido de incorporar a sus discursos y horizonte de pensamiento la reflexión sobre Europa y la aspiración de participar en el proceso de construcción europea (Abdón Mateos, 1989). Ambas cuestiones reforzaron a su vez la reubicación ideológica moderada de la que hablamos: ni los partidos europeos que se tomaron como modelo tenían veleidades revolucionarias ni estas veleidades tenía cabida en el proyecto de unidad europea que se estaba construyendo.

Esta doble europeización del PSOE se debió, en primer lugar, al peso que de cara a su mera supervivencia en el exilio tuvo la ayuda recibida de las organizaciones socialistas europeas, tanto políticas como sindicales; una ayuda que se cifró en apoyos institucionales y financiación económica, pero también en las amplias redes de solidaridad militante que se tejieron a nivel de base en los países de destino (Ortuño, 2005). También se debió a la integración de la UGT y el PSOE en las organizaciones internacionales de la socialdemocracia y al destacado papel que algunos dirigentes socialistas espańoles jugaron en estas y en las incipientes instituciones europeas. La UGT, por ejemplo, participó en la fundación de la Federación Sindical Mundial en 1945, en la Confederación Internacional de Organizaciones Sindicales Libres en 1949 (escisión socialdemócrata de la anterior) y en la Confederación Europea de sindicatos en 1973. Rodolfo Llopis, por ejemplo, fue uno de los promotores del Movimiento Socialista por los Estados Unidos Europeos y participó en el Consejo federal del Movimiento Europeo, en la asamblea de la CECA o en las reuniones preparatorias del grupo socialista del Parlamento Europeo (Mateos, 1989: 345 y 356). Por último, al creciente interés y compromiso con el proyecto europeo pudo contribuir, además de las convicciones positivas, la impotencia del partido a la hora de intervenir de manera determinante dentro de España.

Entre los dirigentes e intelectuales socialistas en el exilio más entusiasmados con la integración europea estuvo Anselmo Carretero, el mismo que tantos esfuerzos dedicó a reflexionar sobre la configuración histórica de España y los modelos preferibles para su organización territorial. De hecho, ambas reflexiones fueron parejas en sus obras del exilio. Su proyecto de una España plurinacional constituida en Estado federal debía conducir a la integración de esta en Europa. Sus ensayos más importantes al respecto fueron España, Europa y los caminos hacia el socialismo (1963), Los pueblos de España y las naciones de Europa (1967) y, sobre todo, España y Europa (1971). En Anselmo Carretero están 
algunos de los antecedentes más explícitos en la transición socialista de la consideración de España como nación de naciones. Tanto es así que muchos años después este intelectual socialista del exilio en México sería reivindicado al respecto por José Luis Rodríguez Zapatero y Pasqual Maragall ${ }^{3}$.

En sus trabajos Carretero expone las razones prácticas que a su modo de ver habían impulsado la convergencia europea y que hacían de ella un horizonte político deseable: una mayor capacidad de competencia económica, la unión como garantía de paz en el continente tras siglos de guerras devastadoras y la conformación de un polo alternativo en términos geopolíticos y de modelo social a los representados por Estados Unidos y la Unión Soviética. Junto a este tipo de razones había otras referidas a la configuración histórica y cultural europea que también daban pleno sentido al proceso de convergencia: trayectorias históricas y rasgos culturales compartidos, otros que se habían desarrollado en paralelo y algunos que, pese a ser tan distintos, resultaban complementarios. Para Anselmo Carretero España formaba parte esencial de Europa, de modo que, tanto por naturaleza histórica como por interés político, Europa debía ser su destino último. No se trataba de solicitar la incorporación de España a la Unión Europea al modo en que una entidad menor suplica ser aceptada en el club de los grandes, sino de reivindicarla apelando al vacío que en todos ellos dejaría su ausencia: "Y desde luego una Europa sin España sería una Europa gravemente mutilada, algo así como una España sin Cataluña o Andalucía (harto rota está ya Iberia por la frontera portuguesa). No podemos concebir una federación de las naciones europeas que excluya para siempre a nuestra patria» (Carretero y Jiménez, 1963: 31 y 32).

El horizonte de convergencia europea aparece en el pensamiento de Anselmo Carretero como leitmotiv de la acción socialista para España. El deseo de ese objetivo es tal que pocas veces se supedita de forma expresa a la democratización previa del país, algo que venía exigiendo la mayoría de los dirigentes del exilio, incluidos los socialistas. Finalmente, para Anselmo Carretero la integración en Europa era la mejor vía al socialismo democrático, no porque entendiera que la integración ofrecía una plataforma de despegue en esa dirección, sino porque a su modo de ver suponía en sí misma un enlace directo con semejante destino, si acaso no su primera anticipación:

Yo, porque soy europeo y socialista, soy europeísta. Creo que el europeísmo es un buen camino para llegar en Europa al socialismo, que era el fin de las asociaciones internacionales de trabajadores formadas en el siglo pasado por socialistas de

3 Véase Pascual Maragall, «Carta abierta a José Luis Rodríguez Zapatero», El País, 4-112002. 
diversas naciones europeas. ¿Y qué mejor asociación internacional de los trabajadores europeos que la unión de todos ellos en una Europa Unida? (Carretero y Jiménez, 1971: 392)

Este proceso de europeización del socialismo español en el exilio fue parejo a otro proceso que pudiéramos llamar de afrancesamiento en algunas de sus tendencias intelectuales y sobre todo en su línea política. A ese afrancesamiento ayudó la tradición educativa española en la que se habían formado buena parte de los intelectuales y dirigentes socialistas, con el aprendizaje del francés como lengua extranjera y el sistema educativo galo como modelo de referencia. Pero a ese afrancesamiento contribuyó sobre todo el hecho de que el núcleo dirigente del PSOE y su base más amplia y mejor organizada residieran en Francia y mantuviesen estrechos vínculos con la SFIO (Ortuño, 2005: 145-155). Esto hizo que el socialismo francés funcionara como referente cotidiano del socialismo español en el exilio, en detrimento, por ejemplo, del laborismo británico, el SPD alemán o la socialdemocracia escandinava. De ahí, en parte, que este proceso de reajuste ideológico general de la socialdemocracia europea se expresara en el PSOE en términos muy particulares, entre otros, por medio de una superposición de esos postulados concretos más contenidos del pacto social de postguerra sobre la retórica maximalista ancestral del partido, que no se depuró, por ejemplo, como en Bad Godesberg. Así, sucedió en cierta medida en la SFIO por razones que tenían que ver, entre otras cosas, con la necesidad de rivalizar ideológicamente con un partido comunista fuerte, con el que al mismo tiempo se quería marcar distancias. Así se produjo en el PSOE, amén de por la influencia de la SFIO, porque también los socialistas españoles tenían que rivalizar y querían marcar distancia con un PCE con amplia presencia en el exilio en Francia y, sobre todo, cada vez más influyente en el interior.

Un ejemplo al máximo nivel lo tenemos en la influencia que Guy Mollet, secretario general de la SFIO, ejerció durante todos aquellos años sobre Rodolfo Llopis, secretario general del PSOE durante casi treinta años en el exilio, de 1944 a 1972. Mollet era un fiel heredero de la tradición guedista (tan propensa a disociar la afirmación de principios socialistas clásicos de una política en el fondo muy pragmática), un europeísta convencido (no en vano fue ministro del Consejo de Europa entre 1950 y 1951), un dirigente más centrado en las cuestiones organizativas e institucionales que en la reflexión teórica e ideológica, un anticomunista en un país donde el comunismo tenía una fuerza considerable y un partidario, en consecuencia, de tejer alianzas con los partidos burgueses de inspiración democristiana (Mateos, 1989: 356 y 357). Si uno observa la trayectoria de Llopis (Vargas, 1999) es como si estos rasgos se hubieran ido transfiriendo a su personalidad política. 
Consecuentemente, entre los rasgos recurrentes en el pensamiento político de muchos exiliados socialistas encontramos una reivindicación orgullosa de la historia del PSOE, una escasa veleidad teórica, la afirmación esporádica y retórica de las viejas aspiraciones de transformación radical de la sociedad, una propuesta más perfilada de cambio para Espańa muy comedida desde el punto de vista social, un anticomunismo acusado, hostilidad a las pulsiones revolucionarias de la nueva izquierda y una voluntad decidida de incorporación y homologación a la familia socialista europea. Tales rasgos pueden percibirse con nitidez en varios escritos de Rodolfo Llopis en el exilio, generalmente publicados por el propio partido o a veces también por instituciones anticomunistas como el Congreso por la Libertad de la Cultura. Sirvan de ejemplo los trabajos España espera su hora. Los puntales del régimen de Franco se quiebran (1958), El problema español (1960) y Etapas del Partido Socialista Obrero Español (1962). Los mismos o parecidos rasgos se perciben en los trabajos de otros intelectuales y dirigentes socialistas procedentes del caballerismo, como puede constatarse en la obra de Francisco Ferrándiz Alborz El PSOE nuevamente de cara a la realidad (1950). Más acusada incluso fue la moderación de Manuel Albar en sus «Tesis política desde el punto de vista socialista», expuestas en la conferencia que impartió en el Ateneo Español de México el 12 de noviembre de 1954 (Albar, 1958).

Este discurso moderado y europeísta fue perdiendo fuerza en el PSOE a medida que, en el nuevo contexto que simbólicamente podríamos situar en torno al 68, entró en el partido la llamada segunda generación del exilio y la nueva generación de militantes del interior. El nuevo contexto lo forzó la oleada huelguística por toda Europa de 1968-1972, que expresaban un amplio malestar popular con respecto al pacto social de postguerra, pues además de haber procurado un reparto muy desigual de sus sacrificios y beneficios en perjuicio de los trabajadores, no satisfacía a una nueva generación de trabajadores que aspiraban a participar también en el control de las empresas. Por supuesto, el cambio contextual lo marcó además el desborde de las protestas estudiantiles y la apertura generacional a nuevos horizontes - liberación sexual, feminismo, crítica del autoritarismo, del consumo y de las formas pautadas de vida - ajenos por completo a una socialdemocracia muy anquilosada y conservadora. Ya fuera por afinidad consciente o contagio contextual, ya fuera por emulación o competencia con los partidos comunistas y la llamada nueva izquierda, el discurso de esta nueva generación de militantes e intelectuales socialistas entroncó con la crítica de la época al capitalismo (base económica de la Europa en construcción), con la oposición a los bloques militares (especialmente al occidental encabezado por Estados Unidos), con la atracción hacia los movimientos de liberación nacional del Tercer Mundo en perjuicio del movimiento obrero europeo clásico y con una cultura militante más enérgica y menos burocratizada (Andrade, 2015: 151-155). 
Sin embargo, esta misma generación que logró hacerse con el poder del PSOE entre los años 1972 y 1974, imponiendo un forzado giro discursivo en cierta medida radical aunque de naturaleza básicamente retórica, retomó tiempo después, al menos desde el último tramo de la Transición española, el proceso de europeización del partido en términos análogos al de sus antecesores del exilio, en el sentido de apostar plenamente por la construcción europea y la integración de España y en el de homologarse a los partidos socialdemócratas europeos renovados, aunque ahora ya tomando como principal referente estratégico e ideológico al Partido Socialdemócrata Alemán (Muñoz Sánchez, 2012).

Todo ello obliga a descartar el tópico de la ruptura ideológica del PSOE de la Transición con respecto al PSOE del exilio, como si alrededor de 1979, fecha en la que tiene lugar la renuncia al marxismo en el XXVIII Congreso, el partido hubiera traicionado, por pura adaptación a unas circunstancias tan limitadas políticamente como esperanzadoras desde el punto de vista electoral, las nobles aspiraciones de trasformación socialista custodiadas tenaz y atemporalmente desde Toulouse. Ni la dirección ni la mayoría de los intelectuales más destacados del partido cultivaron esas aspiraciones durante los casi cuarenta ańos de exilio, en los que evolucionaron generalmente en términos moderados, ni los dirigentes e intelectuales del 79 se rebelaron con respecto a ningún lastre ideológico atávico. Contra lo que se rebelaron, por el contrario, fue contra las tesis maximalistas que ellos mismos habían incentivado unos años antes por mímesis natural con un entorno muy ideologizado para rivalizar calculadamente con las opciones más influyentes de la oposición y para disputarle la dirección del partido, precisamente, a la vieja guardia del exilio, que venía expresándose en esos términos más contenidos. A este respecto cabe hablar de cambio, pero también, sin duda, de continuidad entre el pensamiento y la práctica socialista del exilio y de la tardo-Transición (Mateos, 2017). Tanto es así que en cierto sentido cabe considerar que la ruptura ideológica del exilio socialista con respecto a la República fue más acusada que la ruptura ideológica de los socialistas la transición con respecto al exilio.

\section{CONCLUSIONES}

La Guerra Civil española fue un tema recurrente en el socialismo del exilio. En los primeros años los dirigentes e intelectuales del PSOE, con Indalecio Prieto a la cabeza, se expresaron al respecto en un tono recusativo más orientado al ajuste de cuentas interno que a la comprensión de la contienda. Ello no fue óbice para que tempranamente esbozasen llamamientos en pro de la reconciliación nacional entre los dos bandos enfrentados, como planteó el mismo Prieto y justificó con mayor bagaje intelectual Luis Araquistáin. 
A partir de 1942 se avivaron los análisis acerca de un posible derrocamiento de la dictadura; primero ante la expectativa, al final truncada, de la intervención de los Aliados en España; luego ante la expectativa también fracasada de llegar a acuerdos con sectores desencantados del régimen. La tensión se dio en torno a la disyuntiva de propugnar la continuidad de las instituciones republicanas o, por el contrario, construir un nuevo régimen que permitiera el acuerdo con estos sectores. La tensión se fue incrementando cuando los debates giraron en torno a la forma de legitimar el nuevo régimen: si mediante un referéndum convocado por un Gobierno independiente o a través del enlace de la dictadura con una monarquía restaurada. Entre los promotores de la primera opción estuvo Prieto, entre quienes justificaron la aceptación de esta última posibilidad apelando a la historia del PSOE estuvo Luis Araquistáin.

El exilio entrañó un reforzamiento de la veta liberal que ya venía atravesando al pensamiento socialista español, debido al hecho de que la mayor parte de sus intelectuales de los años veinte y treinta no se habían formado, a diferencia de los intelectuales socialistas centroeuropeos, en la tradición marxista, sino que venían de corrientes regeneracionistas, del krausismo y de la Institución Libre de Enseñanza. Tal fue el caso, por ejemplo, de dos intelectuales de gran ascendencia también en el exilio, Fernando de los Ríos y Luis Jiménez de Asúa. Por otra parte, la pervivencia de la dictadura en España y la terrible experiencia del nazismo - cuyos orígenes culturales fueron analizados por De los Ríos- entrañaron una restimación fuerte de las libertades públicas e individuales. Además, el clima cultural de la Guerra Fría, con el reactualizado discurso de los totalitarismos, empujó a los intelectuales socialistas al campo liberal para evitar cualquier asociación con el del comunismo, previamente equiparado al del fascismo recién derrotado. Esto, sumado a las lecturas de la Guerra Civil, selló una impronta fuertemente anticomunista en los intelectuales y dirigentes del PSOE, como se constata en el caso de Luis Araquistáin, otrora intelectual orgánico del caballerismo revolucionario devenido durante el exilio en firme partidario de la inclusión de la Espańa republicana en la esfera política, militar y cultural atlantista. Pocos intelectuales socialistas, como Max Aub, lograron sustraerse a esta veta anticomunista y a la lógica dicotómica de la Guerra Fría.

El PSOE experimentó una considerable moderación ideológica en el exilio que hizo compatible con la declaración esporádica y retórica de sus viejas aspiraciones maximalistas en los documentos congresuales. En el horizonte real de pensamiento la apuesta por la conquista del poder político por parte de la clase obrera y la subsiguiente transformación socialista de la realidad dejó paso a la aceptación completa de la democracia liberal como marco último en el que promover, sin otro destino finalista, una mayor igualdad social. 
Este giro a la moderación del PSOE se debió a un conjunto de factores que se retroalimentaron. Se debió a una reactualización de sus propias tradiciones intelectuales de fuerte sesgo liberal, encarnadas en algunas de las figuras analizadas, que siguieron teniendo un extraordinario capital simbólico en el partido. Se debió a la influencia de estas sobre las redes culturales que permitían publicar, difundir y avalar trabajos afines. Se debió a cuán contrariado, agotado, desencantado y dividido salió el PSOE de la convulsa experiencia revolucionaria que vivió en el primer tramo de la Guerra Civil. Se debió a la atención preferente a unas posibilidades de cambio político para España que, habida cuenta de la fortaleza de la dictadura de Franco y del peso de la dinámica de bloques de la Guerra Fría, no auguraban muchas posibilidades de transformación socialista del país. Se debió a la seducción que sobre el partido ejercieron los avances sociales que trajo el pacto social de postguerra en los países en los que muchos de sus dirigentes e intelectuales vivían. Y se debió a su peculiar ajuste a un cambio de paradigma ideológico que, de manera consecuente a ese pacto, estaba acusando toda la socialdemocracia europea, de la que tanto dependía el PSOE debido a su condición de partido en el exilio.

Así, el socialismo español se fue europeizando progresivamente en el sentido de equipararse, de forma no obstante peculiar, a los parámetros ideológicos de la socialdemocracia europea y en el sentido de hacer una apuesta fuerte por el proceso de construcción europea, un tema abordado especialmente por intelectuales como Anselmo Carretero. En ello influyó la dependencia de los socialistas exiliados españoles de la cobertura recibida por los partidos socialdemócratas europeos, así como la participación del PSOE, la UGT y de algunos de sus dirigentes en las organizaciones internacionales de la socialdemocracia occidental. Todo ello reforzó la reubicación ideológica moderada del PSOE, ya que ni los partidos europeos que se tomaron como referencia (particularmente la SFIO) albergaban pretensiones revolucionarias ni estas tenían cabida en el proyecto de unidad europea.

No obstante, de todas las influencias recibidas la que tuvo más peso sobre la dirección del PSOE fue la francesa, entre otras razones porque era allí donde residía la mayor parte de la dirección. En virtud de este cruce de influencias, metabolizadas desde la propia tradición, la orientación política e ideológica del PSOE fue adquiriendo unos rasgos muy identificativos, particularmente perceptibles en los escritos e intervenciones de Rodolfo Llopis y otros intelectuales procedentes del viejo caballerismo, como Francisco Ferrándiz Alborz y Manuel Albar. Entre estos rasgos cabe destacar una reivindicación identitaria de la historia del partido, escasas pretensiones teóricas, afirmación ocasional y retórica de las viejas aspiraciones revolucionarias, propuestas muy comedidas de cambio social para España, marcado anticomunismo, recelo hacia la nueva izquierda y aspiración a homologarse a la socialdemocracia europea gobernante. 
El análisis de estas trayectorias ideológicas e intelectuales del socialismo español obliga a descartar el tópico de la ruptura ideológica del PSOE de la Transición con respecto al PSOE del exilio. Contra lo que se rebeló, avanzada la Transición, la joven dirección del PSOE fue más bien contra el radicalismo retórico que ella misma había promovido apenas unos ańos antes para, entre otras cosas, marcar distancias con la envejecida dirección del exilio. Visto con perspectiva cabe plantearse que quizá la ruptura ideológica del socialismo en el exilio con respecto a la República fuera en cierto sentido más acusada que la ruptura ideológica del socialismo de principios de los ochenta con el socialismo del exilio.

Es cierto que el exilio en su totalidad y complejidad fue una presencia incómoda e increpante para la cultura política fraguada en la Transición, pero no fue así en algunas de sus manifestaciones parciales y para nada residuales, concretamente en muchas de las que se advierten en la tradición socialista. Como se ha visto, una tendencia importante del pensamiento socialista rompió no solo con el legitimismo republicano, sino con parte de la cultura política de la República. Esas mismas tendencias influyeron de manera importante en la oposición del interior a la dictadura, en el desarrollo de la Transición y en el devenir de la España postfranquista, en la medida que prefiguraron desde primera hora algunos de sus valores, proyectos y recorridos posteriores. También hubo otras tendencias más sujetas a la memoria del proyecto republicano que ni sucumbieron a las lógicas culturales de la Guerra Fría ni se terminaron identificando con el sistema político construido a la muerte de Franco.

\section{Bibliografía}

Albar, M. (1958). Cartas, artículos y conferencias de un periodista español en México. México: Impresiones Modernas.

Anderson, P. (2015). Consideraciones sobre el marxismo occidental. Madrid: Siglo XXI.

Andrade, J. (2015). El PCE y el PSOE en (la) transición. Madrid: Siglo XXI.

Araquistáin, L. (1953). España ante la idea sociológica del Estado. París: Unión General de Trabajadores; Partido Socialista Obrero Español.

- (1958). La intervención de Rusia en la Guerra Civil Española. México: Cuadernos del Congreso por la Libertad de la Cultura.

- (1959). Franco y el comunismo. Montevideo: Congreso por la Libertad de la Cultura. (1962). El pensamiento español contemporáneo. Buenos Aires: Losada.

(1983). La táctica del Partido Socialista Obrero Español y los acuerdos de París. Discurso pronunciado en el VII Congreso del PSOE en el exilio (Toulouse, 17 de agosto de 1958). En Sobre la Guerra Civil y en la Inmigración. Madrid: Espasa-Calpe.

Aub, M. (1967). Hablo como hombre. México: Joaquín Mortiz.

Aznar Soler, M. (2003). Los laberintos del exilio. Diecisiete estudios sobre la obra literaria de Max Aub. Sevilla: Renacimiento. 
Bourdieu, P. (2012). Intelectuales, politica y poder. Madrid: Claves.

Carretero y Jiménez, A. (1963). España, Europa y los caminos hacia el socialismo. [s. 1.]: Las Españas.

- (1967). Los pueblos de España y las naciones de Europa. México: Editores Mexicanos Unidos. Carretero y Jiménez, A. (1971). España y Europa. Valencia: Fomento de Cultura.

De Hoyos, J. (2016). La evolución del negrinismo en el exilio republicano en México. Historia y Politica: Ideas, Procesos y Movimientos Sociales, 36, 313-337. Disponible en: https://doi. org/10.18042/hp.36.13.

De los Ríos, F. (1921). Mi viaje a la Rusia sovietista. Madrid: Alianza Editorial.

- (1951). ¿A dónde va el Estado? Buenos Aires: Editorial Sudamericana.

- (1956). Ciencia y conciencia. La Habana: Universidad de La Habana.

- (1974). Escritos sobre democracia y socialismo. Madrid: Taurus.

Ferrándiz Alborz, F. (1950). El PSOE nuevamente de cara a la realidad. París: Ediciones Tribuna.

Fontana, J. (2011). Por el bien del imperio. Una historia del mundo desde 1945. Barcelona: Pasado y Presente.

Fuentes, J. F. (2002). Luis Araquistáin y el socialismo español en el exilio (1939-1959). Madrid: Biblioteca Nueva.

Glondys, O. (2012). La Guerra Fría cultural y el exilio republicano español. Cuadernos del Congreso por la Libertad de la Cultura (1953-1965). Madrid: Consejo Superior de Investigaciones Científicas.

Gramsci, A. (2013). Antología. Madrid: AKAL.

Hobsbawm, E. (1998). Historia del siglo XX. Barcelona: Crítica.

Jaume, L. (2004). El pensamiento en acción. Por otra historia de las ideas políticas. Ayer, 53, 109-130.

Jiménez de Asúa, L. (1942). La Constitución politica de la democracia española. Santiago de Chile: Ercilla.

- (1955). Ante España. El PSOE, la democracia, la ley y la universidad. París: Partido Socialista Obrero Español. [Folleto consultado en BNE].

Juliá, S. (1997). Los socialistas en la política española. Madrid: Taurus.

Koselleck, R. (2012). Historia de conceptos. Estudios sobre semántica y pragmática del lenguaje politico y social. Madrid: Trotta.

Llopis, R. (1958). Los puntales del régimen de Franco se quiebran. Toulouse: Partido Socialista Obrero Español. [Folleto consultado en BNE].

- (1960). El problema español. Montevideo: Congreso por la Libertad de la Cultura. [Folleto consultado en BNE].

- (1962). Etapas del Partido Socialista Obrero Español. Toulouse: Partido Socialista Obrero Español. [Folleto consultado en BNE].

Martín Ramos, J. L. (1989). Historia del socialismo español (vol. 4). Barcelona: Conjunto Editorial.

Mateos, A. (1989). Europa en la política de «presencia internacional» del socialismo español en el exilio. Espacio, Tiempo y Forma. Serie V, Historia Contemporánea, 2.

- (2017). Historia del PSOE en transición. De la renovación a la crisis, 1970-1988. Madrid: Silex Ediciones. 
Muñoz Sánchez, A. (2012). El amigo alemán. El SPD y el PSOE de la dictadura a la democracia. Madrid: RBA.

Ortega y Gasset, J. (1990). Meditaciones del Quijote. Madrid: Cátedra.

Ortuño, P. (2005). Los socialistas europeos y la transición española (1959-1977). Madrid: Marcial Pons.

Prieto, I. (1939). Cómo y por qué sali del Ministerio de Defensa Nacional. Intrigas de los rusos en España. Texto taquigráfico del informe pronunciado el 9 de agosto de 1938 ante el Comité Nacional del Partido Socialista Obrero Español. París: Imprimierie Nouvelle (Association Ouvrière). [Folleto consultado en la BNE]

- (1954). Entresijos de la guerra de España (Intrigas de nazis, fascistas y comunistas). Buenos Aires: Bases.

— (1975). Discursos fundamentales. Madrid: Turner.

- (1991). Discursos en América, 1. Con el pensamiento puesto en España. 1939-1944. Barcelona: Fundación Indalecio Prieto; Planeta.

Rivera García, A. (2009). Regeneracionismo, socialismo y escepticismo en Luis Araquistáin. Arbor, 185 (739), 1019-1034. Disponible en: https://doi.org/10.3989/arbor.2009.739n1070.

Ruiz Manjón, O. (2007). Fernando de los Ríos, un intelectual del PSOE. Madrid: Síntesis.

Sánchez Cuervo, A. (2017). La crítica krauso-institucionista del totalitarismo. La obra de Fernando de los Ríos en el exilio. Ápeiron. Estudios de Filosofía, 7, 57-65.

Sassoon, D. (2001). Cien años de socialismo. Madrid: Edhasa.

Skinner, K. (2002). Visions of politics (3 vols.). Cambridge: Cambridge University Press.

Vargas, B. (1999). Rodolfo Llopis (1895-1983). Una biografía politica. Barcelona: Planeta. 